\title{
PAK-US BILATERAL RELATIONS UNDER BUSH ADMINISTRATION
}

\author{
Imran Wakil \\ PhD Scholar (Political Science) \\ Government College University \\ Faisalabad-Pakistan \\ imran.wakil@yahoo.com \\ Dr. Ghulam Mustafa \\ Assistant Professor \\ Department of International Relations \\ Government College University \\ Faisalabad-Pakistan \\ ghulammustafa@gcuf.edu.pk \\ Nida Shabbir \\ PhD Scholar (Political Science) \\ Government College University \\ Faisalabad-Pakistan \\ ahmadnida48@gmail.com
}

\begin{abstract}
Pak-US relations under Bush administration historically reached at its peak. It was the result of his doctrine known as 'Bush Doctrine'. It resulted in constituting a fundamental shift in US foreign policy. This work tried to dig out that how Bush decided to framed his own strategies and way of using power and influence for the pursuit of USA national interests. Unlike president Clinton, president Bush focused on securing geo-strategic rather geo-economic interests. It is also tried to high light that what compelled Bush administration to tilt towards Pakistan. It includes especially inexorable geographical position of Pakistan in the region, so was preferred by US policy makers in this region. Bush even ignored US policy to promote democracy and supported undemocratic rule of General Pervez Musharraf, as his rule was inevitable to secure US national interests in the region. Authorities in Pakistan promised to assist US in its war on terror. It was the same role of Pakistan for which it was
\end{abstract}




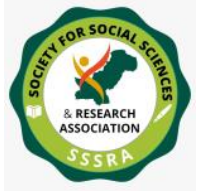

Pak. Journal of Int'L Affairs, Vol 4, Issue 2 (2021)

Pak-Us Bilateral Relations Under ...

given the status of non-NATO ally. Bush Administration in return offered economic and military assistance to Pakistan. This study is based on qualitative insight to find out the real face of Pak-US relations under Bush administration. Secondary data including reports of different institutions, books, research articles and analysis by several scholars have been approached to furnish this work.
\end{abstract}

Key words: Bilateral. Geo-strategic. Inexorable. Terrorism. Unilateralism. Coalition.

\title{
Introduction
}

Talking about the role of US presidents in foreign policy, the critics categorizes them as passive and active. Passive presidents were those who did not make any major change or shift in USA foreign policy. Active were those who brought major change and have influence and even reshaped foreign policy of United States. George. W. Bush is considered as active president who have brought a major shift in foreign policy of USA. There are two groups of foreign policy analysts that view USA foreign policy under Bush administration in different ways. One group claims that foreign policy of USA went through a revolution under Bush administration. (Lindsay, 2003) Second group of analysts describe him as a typical republican president, who followed the policies and style of his party predecessors. Bush opted unilateralism rather than following and continuing multilateralism in USA foreign policy. (Featherstone, 2019) Bush also went forward with his preemptive policies and discontinued policies of deterrence and containment. Same is described by Kelly that unilateralism actually grows due to monochromatic world view (Kelly, 2003). Pak-US relations under Bush administration historically reached at its peak. It was the result of his doctrine known as Bush Doctrine. It resulted in constituting a fundamental shift in US foreign policy. Pakistan has inexorable geographical position in the region, so was preferred by US policy makers while formulating policy towards this region. Bush even ignored US policy to promote democracy and supported undemocratic rule of General Pervez. Presence and support of such ally was inevitable to secure US national interests in the region as he was Chief of Army Staff and the president of Pakistan as well. Authorities in Pakistan promised to assist US in its war on terror. It was the same role of Pakistan for which it was given the status of non- NATO ally. Bush Administration in return offered economic and military assistance to Pakistan.

\section{U.S. response to 9/11 attacks}




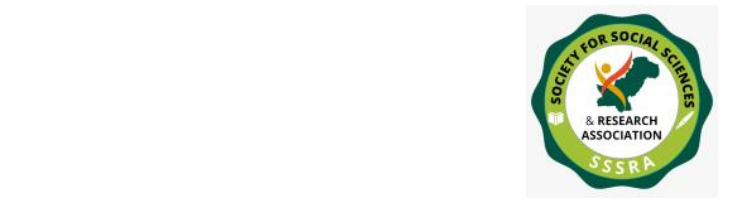

Pak. Journal of Int'L Affairs, Vol 4, Issue 2 (2021)

Pak-Us Bilateral Relations Under ...

The incident of Sep. 11 brought a remarkable shift in US foreign policy. As Nayak (2005) demonstrated that this event reordered US Foreign policy towards the region. Setting aside all agendas, Bush administration focused foreign policy not only to fight against such enemy but to nip the evil in the bud. As it is narrated by Pfiffner (2003) that President Bush believed in decisiveness and was impatient in achieving his goals. In all the eight years of presidency, counter terrorism remained at the top priority of his administration. It was also the time when the leadership of almost all the states were not only coursing terrorism but also stood with US in fighting with such notorious forces. So US campaign against terrorism soon gained popularity and transformed to an international political and military drive. There was no voice against US unilateral stance to defeat terrorist groups like Al-Qaeda, that was claimed to be responsible for attack on US soil (Lindsay, 2003). The objectives were very much clear where it was said that it is war between good and evil. Therefore, the terrorist attack changed the priorities of Bush administration in making foreign policy.

\section{Bush and War on Terror}

National Security Strategy (NSS) of President Bush that was published in 2002, is known as Bush Doctrine. It is actually the principles of his foreign policy, mainly adopted after terrorist attack of Sep. 11. It was US foreign policy package and strategy for self-defense (McGlinchey, 2009). This Doctrine was definitely the spillover effect of a terrorized environment that lately camouflage the whole US foreign policy for more than two decades. This Doctrine constituted fundamental shift in US foreign policy (Snauwaert, 2004). Bush and his administration decided to fight direct war against terrorist groups, especially Al Qaeda. Bush himself went on the stage to play his role in this gory drama (Woodward, 2002). US claimed to create peace in the world, that is possible only after defeating and eliminating terrorist groups in different regions of the world. Maintenance and preservation of peace was declared ultimate objective of Bush Doctrine. Therefore, several policy measures can be seen in US foreign policy that included;

i) Making of such alliances though which US could be able to secure itself and its allies from terrorist activities

ii) Diffusion of regional conflicts by engaging regional players

iii) Protection of world community from weapon of Mass Destruction (WMD)

iv) Strengthening of defense sectors of US to avoid any misshape in future

It was the time when the circumstance compelled US policy makers to analyze that unlike past they must not conquer states with fleets, but need to counter such ideologies that was responsible for terrorist attack in several parts of the world including US. 


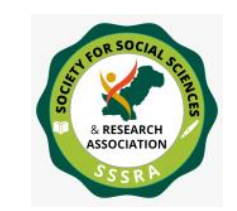

Pak. Journal of Int'L Affairs, Vol 4, Issue 2 (2021)

Pak-Us Bilateral Relations Under ...

\section{New Era of Bilateral Relations}

Pak-US relations remained considerably closed during last decade of twentieth century (Kronstdat, 2001). A new era of bilateral ties between US and Pakistan started in the start of twenty-first century. After the incident of terrorist attack, Bush administration had to rethink in establishing its bilateral relation with several states, as it was not possible for US alone to fight its War on Terror (WOT) in the area that is located at great distance. At the same time Bush and its administration did not allow the world community to keep themselves aloof from WOT. US succeeded to achieve moral as well as physical support of almost all the states and international institutions. US was expecting exchange of intelligence and disruption of such terrorist network in any region where ever required. US strategist and policy makers seemed very conscious about their success against the threat of terrorism (Chaudhry, 2018).

\section{Support to Undemocratic Rule}

Promotion of democracy, institutions, and values as pointed out by Lawson and Epstein (2019) has been considered to be the foreign policy objectives of US. Promotion of democratic rule up in political agenda of Bush. Bush Doctrine was composed of policy objectives where there was a special emphasis on promotion of democratic rule. It is also believed that US national interests can be served better through liberal strategy (Hassan, 2008). It was undemocratic rule that was cursed by Bush and was claimed responsible for numerous evils. Out of the blue, Bush administration ignored this policy objective in the case of Pakistan. In spite of pressurizing Musharraf to transfer political power to civilian rule, Bush admired the rule of Musharraf and his control over political arrangements of Pakistan. US policy makers stated that Musharraf government is inevitable for stability in Pakistan as well as in Afghanistan. It was also assured that USA will continue to offer long term and comprehensive support to Islamabad that is in the best interests of the whole region. Violation of human rights in Pakistan was also ignored by Bush and his administration. All such deviance from the basic policy objectives was to get maximum support from Musharraf government in war against terrorism. Any political clash with position of Musharraf could create hurdles in the way of US to secure interests in the region. Bush knew it better that democracy seems very attractive in a theory but not in practice in Pakistan. Any political inconsistency was not favorable for Bush administration in the wake of WOT. On the other hand, US policy makers were also conscious about the position of military institution in internal and external affairs of Pakistan. It was during his second term when Bush started to talk about civil supremacy in Pakistan 


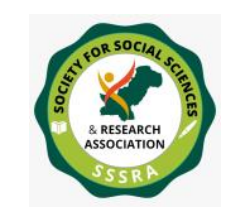

Pak. Journal of Int'L Affairs, Vol 4, Issue 2 (2021)

Pak-Us Bilateral Relations Under ...

\section{Inexorable Position of Pakistan}

As mentioned above, US was not able to succeed in WOT by itself alone. To fight this war, US needed some regional players to join hand with it. The message of President Bush was very clear for its counterterrorism strategy. He made it open to all that one must with US or with terrorists, no third option was given in this matter. This message was actually for the states that are bordering Afghanistan, and predictably had links with such terrorist groups. The terrorist and states that were supposed to assist them were said to be looked with same eyes. Such declaration was a clear indication for Pak-US relations in future. Bush administration presented Pakistan stark choices (Hashmi, 2010.). Bush administration knew the significance of Pakistan in WOT in a much better way. It was definitely impossible to intervene in internal matters of Afghanistan without taking Pakistan in confidence. It was also called a U-turn in US foreign policy towards Pakistan, as Pakistan was being ignored after the end of Cold War by the US policy makers. Geostrategic location of Pakistan, having a long border with Afghanistan made it more attractive for US strategist, especially at the time when they were planning to fight war against terrorists. This border of almost 2300 kilometer could not be ignored, especially when both states across the border not only belong to same religion but also have common culture, history and ideology. Bush administration had also a clear idea that how much porous this border can be proved in a situation where Pakistan was not given proper place while planning war in Afghanistan. At some later stages it proved true when some of Taliban leaders succeeded to cross the border to find safe sanctuaries at the border area of Pakistan side. For the same reason special attention was given to surveillance on Pak-Afghan border. US itself was evident of defeat of USSR in Afghanistan, so US did not take risk to ignore Pakistan in such regional issue. Bush administration was aware about relations between Pakistan and Taliban government in Afghanistan. Therefore, Pakistan became the major ally of US in its war on terror (Mumtaz, 2019). There was no state other than Pakistan that could have greater influence in the internal matters of Afghanistan. In Afghanistan, Pakistan was supporting government of Taliban as it was in its best strategic and regional interests. Moreover, Nuclear capacity of Pakistan caught more attention of Bush administration to involve Pakistan in its WOT. US was one of those states who claimed that Nuclear arsenal of Pakistan are not in safe hand. US was very suspicious about Islamist mind set in Pakistan military forces. The whole episode of war on terror is evident that Pakistan has been frontline state in this war (Tallis, 2008)

\section{Hard Decision by Pakistan}




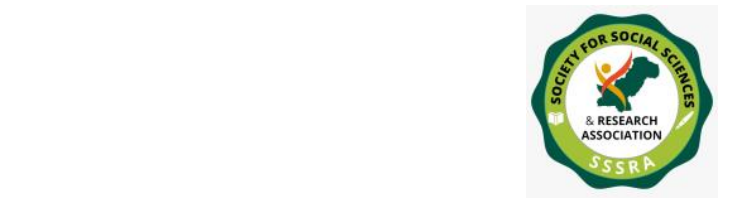

Pak-Us Bilateral Relations Under ...

It was not an easy decision for Pakistan to join hands with US on its war against terrorist groups. As Yamin (2015) elaborated that prevalent situation of that time compelled Pakistan to act as wished by Bush administration. After US declaration of war, Pakistan tried to talk and convince Taliban to accept what US was demanding, mainly handing over of the two top leaders, Osama Bin Laden and Mullah Omer. Unfortunately, all these efforts of Pakistan went in vain and Pakistan had to join US to fight with Terrorist groups in Afghanistan. US was not demanding only simple collaboration from Pakistan to achieve its objectives in the region. Several terms and conditions were presented to Pakistan that must be observed as US ally to defeat Terrorists in the region. These term and condition included;

i) Provision of permission to use air spaces by US air forces

ii) Provision of access to use air as well as naval basis along with locations of strategic significance along Pak-Afghan border

iii) Intelligence sharing with US forces particularly about Taliban and Al Qaeda

iv) To cultivate public opinion to condemn terrorist attack of 9/11

v) Discontinuity of any assistance to Taliban, if they are getting from across Pakistan border

vi) Dismissal of diplomatic relation with Taliban Government in Afghanistan.

vii) Stoppage of Al-Qaeda operatives along Pakistan borders

It seems that "United States has imposed U.S. policies and interests on Pakistan, rather than working with Pakistanis to help define their objectives and find ways to support their efforts to achieve them." (Dormandy, 2012)

\section{Reason for Pakistan to Side with US}

Pakistan at that time itself was surrounded by several internal and external issues. Therefore, General Pervez Musharraf, president and chief of army staff, decided to side with US and accepted all the above mentioned terms. He was aware that such Pak-US cooperation will serve mutual interests as it was done in past. (Hussain, 2005) So, Pakistan had to decide to join WOT for the following reasons;

i) There was very clear message of president Bush that either you are with us or with terrorist. So Pakistan was not left with any option.

ii) Pakistan itself was not safe from terrorist attacks, terrorism is Pakistan had started to take the shape of religious extremism.

iii) Pakistan needed to improve its tarnished image in the eyes of international community, where it was being labeled as state with extremist ideology or even a terrorist state. 


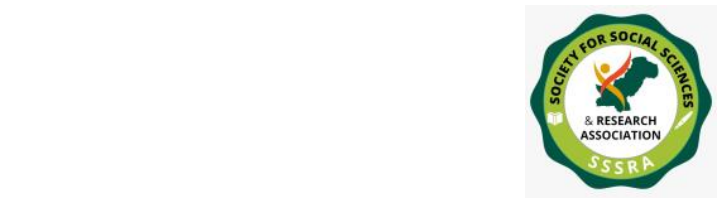

Pak-Us Bilateral Relations Under ...

iv) President General Pervez Musharraf himself intended to prolong his rule by provide support to US in a deal of ignoring his undemocratic rule.

v) Huge economic and military assistance was also attractive for Musharraf to avoid any further economic or security issue during his rule.

vi) Security of strategic assets was necessary to assure at that particular situation when questions were raised and it was claimed that they are not in safe hands.

vii) Pakistan never want anti-Pakistan government in Afghanistan, so needs its role in the changing circumstances of Afghanistan.

\section{Pakistan and US Coalition on WOT}

As demonstrated by Cohen (2006) that at one side Pakistan finds itself at a critical juncture, on the other position of Pakistan could not be disregarded by US to fight war against terrorism in the region of South Asia. Geographical proximity and tribal areas in Pakistan had made it inevitable for US to involve Pakistan in its WOT. Policy makers in USA were very much clear about position and role that Pakistan could play to achieve their goals in this region. Therefore, one can count following reasons that persuaded USA to make Pakistan its partner in WOT;

i) Geo-strategic significance of Pakistan can never be underestimated while making any plan such like WOT in the region of South Asia. Such position of Pakistan made it inevitable to maintain peace and stability in the whole region. Pakistan shares a border of almost twenty-two hundred kilometers with Afghanistan. So, the role of Pakistan is vital for long lasting peace and stability in the case of Afghanistan. USA needed cooperation of Islamabad in its campaign against terrorists as it has also been pointed out by Kreft (2008) that geo-strategic importance of Pakistan cannot be over looked.

ii) Pakistan nuclear Washington has special concerns for nuclear weapon of Pakistan. USA leaders stated time and again that nuclear weapon of Pakistan are not safe hands. They believed that the extremist could have access to these weapons. This concern is due to religious sentiment both in society and in defense forces of Pakistan. Some of critics even did not hesitate to call nuclear bomb of Pakistan as 'Islamic Bomb'. It is righty said by Tkacik (2010) that US and its allies have several concerns about nuclear weapons of Pakistan

iii) Politically stable and peaceful Pakistan has been thought in the best interest of USA during its WOT in Afghanistan. Vulnerability of Pakistan can prove a direct threat to USA interests in the region. US president showed concerns for stability of Pakistan as a 


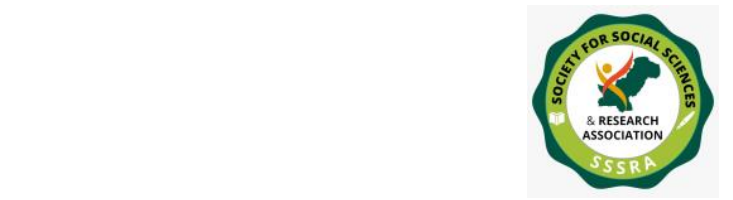

Pak. Journal of Int'L Affairs, Vol 4, Issue 2 (2021)

Pak-Us Bilateral Relations Under ...

nation state (Chari, 2010). Political strength and strong will of Pakistan government could support USA in achieving its long term interests in the region.

iv) Policy making authorities in USA were aware about links and relationship history of Taliban and Pakistan. Taliban were considered to counter Indian interests in Afghanistan, so remained close to Pakistan. Moreover, these Taliban have deep tribal, racial, cultural, territorial and religious attachments with the people living in Pakistan. As it is claimed by Waldman (2010) that Pakistani forces have direct or indirect links with Taliban leaders in Afghanistan.

\section{Role of Pakistan in Operation Enduring Freedom}

Terrorist incident of September, 2001 caught USA and its leaders completely off guard. It was first direct attach on US soil after Pearl Harbor. It was narrated by Smith and Ziegler (2017) now the world has become more vulnerable and unstable as compare to the past This incident created a sense of unity among the nation and political players of USA. There was hardly any second opinion on the decision of Bush administration to plan a war against terrorist in Afghanistan. Bush administration soon succeeded to establish international coalition on the agenda to eliminate the terrorist, who have become the threat to the security of the whole world. The next task for Bush administration was to plan a comprehensive strategy to make this war successful. While making strategy regional facts were kept in mind. Operation Enduring Freedom was planned by Bush administration. Though unlike ISAF, it was not authorized by Security Council of United Nations, but US continued it under the umbrella of self-defense (Shah, 2010.).

Ground realities brought policy makers of USA at one page, where they decided to get Pakistan involve in the Operation Enduring Freedom. Akhtar (2011) stated that the incident of 9/11 caused to bring Pakistan and US closer to each other It would not wrong if one says that USA could not be able to achieve its goals in WOT without assistance provided by Pakistan. All long term objectives of USA were highly dependent on the willingness of authorities in Pakistan to involve in WOT. USA policy maker could not afford mistake done by Soviet Union, where Soviet leaders under estimated role of Pakistan in the regional issues, especially in Afghanistan. Soviet forces failed to get control over local groups of Afghanistan and ultimately had to withdraw. Soviet Union also spent huge amount and used its military forces in Afghan war. Missing of cooperation from Pakistan proved a major fault in its strategy that proved fatal for it. USA in its WOT, succeeded to win cooperation from Pakistan. Pakistan government and military forces did best to assist USA forces to accomplish its task to tackle with terrorist 


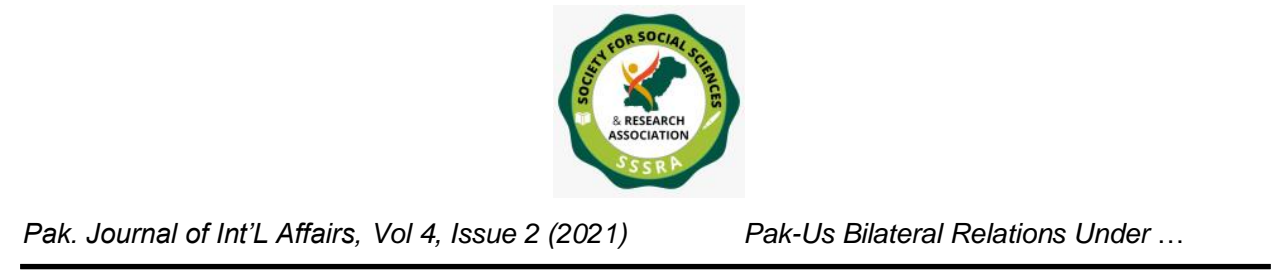

groups in Afghanistan. Authorities in Pakistan assured US to provide all kind of support (Yamin, 2015). Pakistan provided air basis, shared intelligence, provided all types of facilities to USA forces in Afghanistan to achieve the goals of Operation Enduring Freedom. It is admitted that OEF remained successful with special assistance provided by Pakistan (Perl, 2007).

\section{US Assistance to Pakistan During Bush Era}

It is reality that at the time of decision to cooperate in WOT, that time president of Pakistan, General Pervez Musharraf, thought to get economic assistance along with other benefits for his government in return of such cooperation with USA. Bush administration was aware about the weaknesses of Musharraf and his rule, so was offered with handsome economic and military assistance as reward. US intended to boost economic condition and enabling it militarily to fight against terrorists (Zainab Ahmad). Musharraf took it as blessing to support his dwindling economy and illegitimate rule. USA the champion of democracy ignored undemocratic rule in Pakistan, as it was its own favor. USA it was happy with such give and take that was actually not a big deal for it to achieve its long lasting political and strategic objectives in South Asia. It would not be wrong to say that USA was actually investing and buying the support from Pakistan that is an important player in the region. Bush promised about $\$ 3$ billion for next five years in a meeting with Musharraf held in Camp David in 2003. Unlike fluctuations in past, US assistance to Pakistan raised continuously after 9/11 (Kronstadt, 2011). Bush administration labeled the following objectives for its assistance to Pakistan;

i) Maintenance of peace and security in the region.

ii) Support for democracy

iii) Investing for uplift of public

iv) Economic uplift

v) Humanitarian assistance

With this deal USA secured assistance from Pakistan security forces in its WOT. At the same time Musharraf got support for his weak economy and illegitimate rule. Pakistan was being ignored by USA policy makers since last few decades. This episode provided Pakistan an opportunity to develop close ties with USA. Now Pakistan was one of those states which were attracting the attention in foreign policy of USA.

\section{Military Aid under Security Cooperation Agenda}




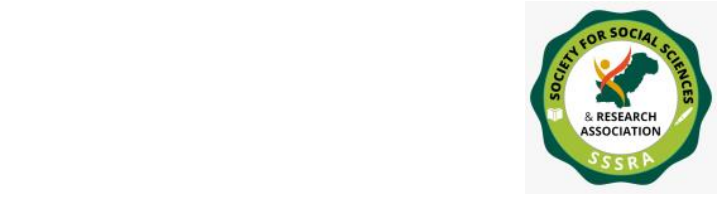

Pak. Journal of Int'L Affairs, Vol 4, Issue 2 (2021)

Pak-Us Bilateral Relations Under ...

Economic aid to Pakistan was thought to be useless without military aid, as the main aim of USA was security of the region. Pakistan that was once being tolerated harshly and blamed for nuclear proliferation, has been offered with military assistance by the same USA. After a long break, bilateral military and security cooperation between Pakistan and USA was revived. So, the incident of terrorist attack provided a new start to the bilateral relations. The security assistance provided by USA was aimed at strengthening and enhancing capability of Pakistan for counterterrorism at its border areas. Funding was provided to construct roads in the western Pakistan that was the most affected area. Transport helicopters, aircrafts, night vision equipment, communications gears and protective vest were among the other security relevant material provided by USA. Pakistan Army Air Assault unit was undertaken to train to increase its capacity to move faster to find and attack required targets. Security assistance was also provided to the civilian sector of Pakistan. It included, training of police to enhance it capabilities of law enforcement agencies, establishment of a Counterterrorism Investigation Group and introduction of advance identifications system. US military assistance to Pakistan reached \$3.6 billion till 2006. (Greg Bronu, 2021)

In 2008, Pakistan was the largest receiver of military aid provided by USA. U.S-Pakistan Defense Consultative Group was also made active in September 2002. The purpose of this groups was to discuss defense and security cooperation to counter terrorist activities in the region. Join military exercises between Pakistan and USA forces have also been done in the same years. Tripartite Commission of Afghanistan, Pakistan and USA was established in 2003. Under this commission the military commanders were supposed to sit together to discuss stability in Afghanistan and security issues on Afghan Pakistan border. Coalition Support Fund was also established to estimate additional cost that Pakistan military will incurred in fighting terrorism. Pakistan was asked to appoint its military personals for the vigilance of Pak- Afghan border. Arms sale agreement between Washington and Islamabad reached \$ 836 million during 2003-05. Moreover, 36 F-16 advanced air crafts have also been included in US-Pakistan arms sales in 2006. These arms along with P-3C maritime petrol aircrafts and anti-armor missiles were considered having anti-terrorism applications. (Kronstadt, 2011)

\section{Status of Non NATO Ally}

WOT made USA once again closer to Pakistan. The role and efforts of Pakistan military forces have gained the special place in the foreign policy of USA. Colin Powel, the than secretary of State of USA met with Foreign Minister of Pakistan Shah Mehmood Qureshi on March 2004. After this meeting Both of them held a joint press conference. At that movement Powel talked about a special message of Bush administration. He told that 


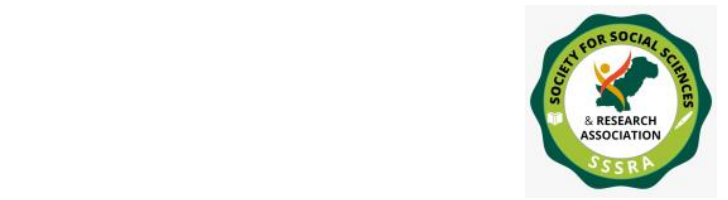

Pak. Journal of Int'L Affairs, Vol 4, Issue 2 (2021)

Pak-Us Bilateral Relations Under ...

USA intend to develop close ties with Pakistan. He also explained the bonds between the two states developed in recent years. Mr. Powel also appreciated the efforts of Pakistan in the WOT. It was the time when Pakistan was conducting an operation in Tribal areas of Pakistan to hunt the terrorists along border side. He unveiled that Bush administration has asked Congress to provide Pakistan the status of non NATO ally. Finally, Bush administration succeeded to get endorsement from Congress and Pakistan was given status of Non NATO ally in June 2004. In this way, Pakistan became twelfth state to enjoy this special status. A state that is given this status means that it will receive preferential treatment in the area of economic and defense. This status was given in appreciation of the role of Pkistan in the war on terror. (Javaid, 2005)

\section{Drone Strikes Under Bush Administration}

Bush administration did not restrict its WOT to Afghanistan. USA forces followed terrorists in border area Pakistan side. The first drone strike by USA forces remained very successful in which a militant commander Mohammed Atef was killed (Rowland, 2013). It was the start of series of drone strikes by USA to hunt terrorists. During Bush era dozens of drone strike was made in Pakistan. Actual campaign of drones was started in the last year of the second term of president Bush. In these strikes many terrorists were killed, few of them were among renowned and were most wanted to USA forces, but most of them were from low ranking Taliban. In 2010 a militant while talking with New Times reporter "It seems they really want to kill everyone, not just the leaders." (Rowland, 2013). At that time Bush decided to get noticeable success in his WOT. Terrorist that fled to the tribal areas of Pakistan were not left unattended and attacked through drones. Bush authorized forty-eight (48) drone strikes in his two terms as president. It was also the time when Pakistan faced immense pressure from Bush administration to do more to assist USA in its WOT. It was not easy for Pakistan to coordinate with USA in its drone strikes, as it was a direct challenge to the sovereignty of the state. In its second term, Bush administration did not even take Pakistan in confidence to hunt terrorist in its border areas.

\section{Conclusion}

Pak US. relations never remained consistent. Historically, relation between these two partners can be defined as issue based. Under Bush administration there was a clear shift in US policy towards Pakistan. It was incident of 9/11 that compelled the policy maker of US to give Pakistan some extra ordinary space while formulating foreign policy towards South Asia. Pakistan that was surrounded by several problems, had to side with US in its WOT. Geographical contingency of Pakistan pushed it in this war. As a reward US 
offered special economic and military packages for Pakistan. Pakistan remained front line ally of US during its two-decade war in Afghanistan. These were the same services provided by Pakistan for which it was given the status of non-NATO ally. 


\section{References}

Akhtar, N. (2011). Pakistan and US Partnership: Cost or Benifits. International Journal of World Peace, 7-31.

Chari, P. (2010). Pakistan's Stability: The Global Stackes. Institute of Conflict and Peace Study, 1-5.

Chaudhry, G. M. (2018). Historical Perspective of Pakistan-US Relations and The USA's Afghanistan and South Asia Strategy: Implications for National Security of Pakistan With Policy Options to Maintain Strategic Balance in South Asia. Journal of Research Society of Pakistan, 37-50.

Cohen, S. P. (2006). With Allies Like This: Pakistan and The Wat on Terrorism. Washington DC: Hoover Press.

Dormandy, X. (2012). Reversing Pakistan's Descent: Empowering its Middle Class Vol. 35, No. The Washington Quarterly, 157-173.

Featherstone, C. (2019). George W. Bush's foreign policies: principles and pragmatism. Journal of International Affairs, 505-509.

Greg Bronu, J. B. (2021, 08 15). US-Pakistan Military Cooperation. Retrieved from https://www.cfr.org/backgrounder/us-pakistan-military-cooperation: https://www.cfr.org/backgrounder/us-pakistan-military-cooperation

Hashmi, R. S. (2010.). War on Terrorim: Implications for Pakistan's Economy. Journal of Politics and International Studies, 1-15.

Hassan, O. (2008). Bush Freedom Agenda: Ideology and Democratization of The Middle East. Taylor and Francis, Lmt., 268-289.

Hussain, T. (2005). US-Pakistan Engagement; The War on Terrorism and Beyond. Washington DC: United States Institute for Peace.

Javaid, U. (2005). Pakistan's Non NATO Ally Status. Asian Profile, 50-62.

kelly, M. J. (2003). The Bush Foreign Policy 2001-2003: Unilateralist Theory In Multilateral World, And Oppertunities For Change Offerfed by Iraq. Washington University Global Studies Law Review, 221-229.

Kreft, H. (2008). The Geopolitical Importance of Pakistan: A Country Caught Between The Threat of Talibanisation and The Return to Democracy. Institute for Strategic, Political, Security and Economic Consultancy, 1-5. 
Kronstadt, S. B. (2011). Pakistan: U.S. Foreign Assistance. Washington DC: Congressional Research Service.

Kronstdat, K. A. (2001). Pak-U.S. Relations. Washington DC: Congressional Research Service.

Lindsay, I. H. (2003). America Unbound; The Bush Revolution in Foreign Policy. Chicago: Brookings Institution Press.

Marian L. Lawson, S. B. (2019). Democracy Promotion: An Objective of U.S. Foreign Assistance. Washington DC: Congressional Research Service.

McGlinchey, S. (2009). International Law and Bush Doctrine. E-International Relations, 1-5.

Meagan Smith, S. M. (2017). Terrorism Before and After 9/11- A More Dangerous World. Research and Politics, 1-8.

Mumtaz, S. (2019). Kashmir Resolution: A case study of Musharaf Era in Pakistan. Journal of Politics and International Studies, 85-104.

Nayak, P. (2005). US Security Policy in South Asia Since 9/11- Challenges and Implications for the Future. Asia Pacific Center For Security Studies, 2-15.

Pak-US Relations Post 9/11: Impact of Aid, I. a.-2. (2015). Zainab Ahmad. Journal of Politics and International Studies, 14-23.

Perl, R. (2007). Combating Terrorism: The Challenge of Measuring Effectiveness. Washington DC: Foreign Affairs, Defence and Trade Division.

Pfiffne, J. P. (2003). The Modern Presidency. Boston: WADSWOTH CENGAGE LEARNING.

Rowland, P. B. (2013). Drone Wars. The Washington Quarterly, 7-26.

Shah, S. A. (2010.). War on Terrorism: Self-Defense, Operation Enduring Freedom, and the Legality of U.S. Drone Attacks in Pakistan. Washington University Global Studies Law Review, 77-127.

Snauwaert, D. T. (2004). The Bush Doctrine and Just War Theory. The Online Jouranal of Peace and Conflict Resolution, 121-135.

Tallis, A. J. (2008). Pakistan and the AWar on Terror: Conflicted Goals, Compromised Performance. Carnegie Endowment For International Peace, 1-48.

Tkacik, M. (2010). Pakistan Nucear Weapon Program and Implications for US National Security. Faculty Publications, 1-64. 
Waldman, M. (2010). The Sun in The Sky: The Relationship Between Pakista's ISI and Afghan Insurgents. Crises State Reseach Center, 1-27.

Woodward, B. (2002). Bush at War. new Yark: Simon and Schuter Rockefeller Center.

Yamin, T. (2015). Examining Pakistan's Strategic Decision to Support US War on Terror. Strategic Studies, 113-135. 